\title{
Prevalence and antibiotic resistance of Staphylococcus aureus and Streptococcus agalactiae in family-owned dairy herds in the state of Minas Gerais, Brazil
}

\author{
Alan Andrade Mesquita ${ }^{1}$, Geraldo Marcio da Costa*, \\ Marina Romano de Oliveira ${ }^{2}$, Sandra Maria Pinto ${ }^{3}$, Jerry Carvalho ${ }^{2}$, \\ Dircéia Aparecida da Costa ${ }^{2}$, Délcio Bueno da Silva ${ }^{4}$
}

\begin{abstract}
RESUMO
A mastite bovina é a doença mais frequente em rebanhos leiteiros no mundo todo, acarretando grandes prejuízos econômicos para os produtores e a indústria. A doença também tem implicações na saúde pública, devido ao potencial zoonótico de alguns agentes envolvidos em sua etiologia e à presença de resíduos de antibióticos no leite. Considerando o aspecto multifatorial da doença e a importância da produção de leite na agricultura familiar, o conhecimento dos agentes envolvidos em sua etiologia e os perfis de suscetibilidade aos antibióticos é de suma importância. Neste estudo, avaliaram-se as prevalências de Staphylococcus aureus e Streptococcus agalactiae em rebanhos de propriedades de agricultura familiar, na região do Campo das Vertentes, Minas Gerais, e também se analisou a resistência destes patógenos aos antibióticos mais comumente utilizados no tratamento da mastite em rebanhos leiteiros. O estudo envolveu 200 propriedades, abrangendo uma área de aproximadamente $12.564 \mathrm{~km}^{2}$. As prevalências dos patógenos $S$. aureus e $S$. agalactiae foram obtidas por meio de análises microbiológicas de amostras de leite do tanque de expansão de cada propriedade. Para a deteç̧ão de $S$. aureus, utilizou-se o meio seletivo Ágar Baird-Parker modificado e, para a deteç̧ão de $S$. agalactiae, o meio seletivo Ágar Edwards modificado, enriquecido com $5 \%$ de sangue ovino desfibrinado. Foi utilizada a técnica de difusão em discos para a avaliação de resistência aos antimicrobianos. Os resultados indicaram altas prevalências dos patógenos $S$. aureus $(71,0 \%)$ e $S$. agalactiae $(68,0 \%)$, com elevados níveis de
\end{abstract}

\footnotetext{
${ }^{1}$ Instituto Federal de Educação, Ciência e Tecnologia de Rondônia - Campus Colorado do Oeste

${ }^{2}$ Universidade Federal de Lavras, Department of Veterinary Medicine

${ }^{3}$ Universidade Federal de Lavras, Department of Food Engineering

${ }^{4}$ Instituto Federal de Educação, Ciência e Tecnologia do Sul de Minas - Campus Muzambinho

* Corresponding author: gmcosta@ufla.br - Departamento de Medicina Veterinária da Universidade Federal de Lavras - Lavras, Centro/Minas Gerais CEP 37200-000 CP 3037
} 
resistência frente à polimixina $\mathrm{B}$, penicilina $\mathrm{G}$ e ampicilina. $\mathrm{O}$ fenômeno da multirresistência foi observado a níveis elevados para ambos os patógenos. Os resultados demonstram que há falhas no controle da mastite contagiosa nos rebanhos estudados, apontando para a necessidade de medidas mais efetivas para o controle destes patógenos e do uso mais criterioso dos antibióticos, visando minimizar o problema da resistência ao medicamento.

Palavras-chave: Mastite, Qualidade do leite, Contagem de células somáticas, Produção de leite.

\section{Introduction}

The Brazilian food production is intrinsically related to small farms, especially family farming, which represents approximately $84 \%$ of all properties and yields US $\$ 55.2$ billion in revenue annually. The Brazilian family farming segment ranks in the eighth position amongst the largest food producers in the world (MAPA, 2017).

Milk production is one of the main activities developed in family farming, accounting for $52 \%$ of the revenue of these properties; it represents an important complement to household income, playing an important role in local economy (GUANZIROLI; CARDIM, 2000; BEZERRA; SCHLINDWEIN, 2017). The State of Minas Gerais is the largest milk producer in Brazil. In 2016, approximately 6.5 billion liters of milk were produced in the state, which represented $26 \%$ of the milk purchased by the Brazilian industry that year (IBGE, 2017).

Despite the importance of this activity, the Brazilian milk production segment has large bottleneck. One of the main ones is still the low productivity of animals, with a national average of only $1,381 \mathrm{~kg}$ milk/cow/year, while the US produced on average $9,790 \mathrm{~kg}$ milk/cow/year in 2012 (USDA, 2012). The low productivity of cows and consequently of Brazilian dairy herds has multifactorial causes. Sanitary aspects plays a leading role, especially because of the endemic occurrence of mastitis. This is the most frequent disease and the greater cause of losses in dairy farms worldwide (KEEFE, 2012). 
The economic losses caused by mastitis are associated mainly with reduction in milk production, increased labor costs, including veterinary services, drug spending, and milk discard of affected animals, early death or animal disposal (OVIEDO-BOYSO et al. al., 2007; LOPES et al., 2012). In addition to direct losses to producers, this disease promotes changes in milk composition associated with increased bulk milk somatic cell count (BMSCC) and low milk quality (LANGONI et al., 2011).

Among the mastitis-causing bacteria, the contagious pathogens Staphylococcus aureus and Streptococcus agalactiae are usually associated with more severe damage to the mammary gland as compared to other microorganisms (REYHER et al., 2012). These bacteria are the most common causes of mastitis in Brazilian dairy herds (OLIVEIRA et al., 2009; SAAB et al., 2014). Studies focusing on S. agalactiae showed that it was present in $60 \%$ of the properties in the Zona da Mata region, State of Minas Gerais (BRITO et al., 1999), and in $39.7 \%$ of farms in different municipalities in the state (ELIAS et al., 2012). In addition to their high prevalence, other studies have pointed to their increased resistance to antimicrobials (BRITO; BRITO, 2001; OLIVEIRA et al., 2012; ALENCAR et al., 2014).

Oliveira et al. (2013) studied approximately 6,000 lactating cows from 112 herds in the States of Minas Gerais and Rio de Janeiro, and found a prevalence of $93.0 \%$ for $S$. aureus and $41.0 \%$ for $S$. agalactiae. In another study, Cunha et al. (2015) found a prevalence of $55.4 \%$ for subclinical mastitis in dairy herds in the municipality of Viçosa, in the Zona da Mata region (State of Minas Gerais), with Corynebacterium spp. (32.99\%), $S$. aureus $(28.35 \%)$ and $S$. agalactiae (13.66\%) as the most frequent isolated etiological agents. Besides the direct losses that $S$. aureus and $S$. agalactiae cause to producers, the simple presence of these pathogens in milk can be indicative of low quality, especially when it comes to milk quality indicators such as total bacterial count (TBC) and BMSCC (PETER et al., 2013). 
Bovine mastitis is a disease that requires antibiotics, which is mostly administered to treat clinical cases, and dry cow therapy (ERSKINE et al., 2004). This, however, increases the risk of antimicrobial residues in milk and derivates. The continuous, reckless antibiotic treatment is a determining factor for selecting resistant strains, potentially harmful to public health (OIE, 2010). The dry cow therapy, associated with high BMSCC and a history of mastitis, has potential for selecting antibiotic resistant strains (RAJALA-SCHULTZ et al, 2009).

The high prevalence of mastitis in Brazilian herds and its economic and health impacts require periodic monitoring of both the pathogens involved in its etiology and their antibiotic susceptibility. In addition, it is important to study the resistance of the bacteria involved in intramammary infections (IMI) to antibiotics that are commonly used against mastitis. This allows for monitoring the resistance dynamics and adopting more effective treatment protocols to combat the disease.

This study evaluates the prevalence of $S$. aureus and $S$. agalactiae in bulk milk tanks of small dairy herds in the Campo das Vertentes region, in the south of Minas Gerais. It also analyzes their resistance to the antibiotics that have been commonly used to treat bovine mastitis.

\section{Material and methods}

This study analyzed the bulk milk tank samples from 200 dairy herds located in the Campo das Vertentes region (approximated of $12,564 \mathrm{~km}^{2}$ ). Since the properties were family farms, i.e., had less than 4 fiscal modules (less than 120 hectares), they produced less than 350 liters of milk/day and predominately employed family labor (ZOCCAL; SOUZA; GOMES, 2004). Probabilistic criteria were not used to choose the properties. The inclusion of farms was based on the previous relationship of the milk industry with the research unit. 
A descriptive study was carried out in the properties to evaluate the prevalence of the pathogens $S$. aureus and $S$. agalactiae. To this end, samples of approximately $40 \mathrm{~mL}$ of bulk milk were collected in expansion tanks after homogenization. The samples were stored at $-20^{\circ} \mathrm{C}$ for up to two weeks before the microbiological analyses. Freezing milk samples at $-20^{\circ} \mathrm{C}$ for up to six weeks does not appreciably affect the recovery rate of Staphylococcus aureus and Streptococcus agalactiae in milk samples submitted to microbiological analysis (OLIVER et al., 2004).

To detect $S$. aureus, an aliquot of $50 \mu \mathrm{L}$ of each milk sample was spread in a Petri dish containing modified Baird-Parker Agar selective medium, which was incubated at $37^{\circ} \mathrm{C}$ for $24-48$ hours. After incubation, colonies in dark gray to black color, glossy, convex shape, with $1-5 \mathrm{~mm}$ of diameter and a clear 2-5-mm-wide halo at their periphery were characterized as positive for $S$. aureus (SCHOELLERS; INGHAM, 2001).

To detect $S$. agalactiae, an aliquot of $50 \mu \mathrm{L}$ of each milk sample was spread in modified Edwards Agar Selective Medium Petri dishes enriched with 5\% defibrinated sheep blood. The plates were incubated for 24-48 hours at $37^{\circ} \mathrm{C}$. Colonies that had a bluish color, bright appearance and convex shape, 1-5 $\mathrm{mm}$ in diameter, with or without an opaque zone on the periphery, were considered positive (SAWANT et al., 2002).

After evaluating the growth in the selective media, five suggestive colonies of each agent of interest were selected at random and submitted to confirmatory tests for precise species identification, including sugar fermentation tests and CAMP test for characterization of $S$. agalactiae, and acetoin production (VP test), hemolysis, coagulase and mannitol fermentation for identification of $S$. aureus (NMC, 2004). After characterization, the microorganisms were stored in BHI containing glycerol $(15 \% \mathrm{v} / \mathrm{v})$ at $-20^{\circ} \mathrm{C}$ until susceptibility tests were performed.

For antibiotic susceptibility testing, three strains of $S$. aureus randomly selected from each of the $S$. aureus positive properties were pooled 
and used to evaluate antimicrobial susceptibility. The same procedure was done to evaluate the susceptibility of $S$. agalactiae isolates. In total, 74 antibiograms were performed for $S$. aureus and 65 for $S$. agalactiae.

In-vitro antibiotic resistance tests were performed by the disk diffusion method (CLSI, 2013). To this end, the strains were thawed, and an aliquot of $10 \mu \mathrm{l}$ was cultivated in tubes containing $2 \mathrm{ml}$ of Mueller Hinton broth, incubated at $37^{\circ} \mathrm{C}$ for $18-24$ hours after evaluation of growth and purity, and then diluted in sterile saline until 0.5 turbidity equivalent to McFarland standard scale to produce the inoculum.

The standardized inoculums were spread on a culture media plate surface containing Mueller-Hinton Agar, which is supplemented with 5\% sheep blood for $S$. agalactiae susceptibility tests. The antibiotics tested were: ampicillin $(10 \mathrm{mcg})$, cephalothin $(30 \mathrm{mcg})$, cefotaxime $(10 \mathrm{mcg})$, cefoperazone (15mcg), ceftiofur (25mcg), chloramphenicol (10 mcg), enrofloxacin (5mcg), florfenicol $(30 \mathrm{mcg})$, gentamicin $(10 \mathrm{mcg})$, lincomycin $(15 \mathrm{mcg})$, nitrofurantoin (20 mcg), novobiocin (10 mcg), polymyxin B (30 mcg), penicillin G (10mcg), oxacillin (15mcg), sulfazotrim (25mcg), tetracycline $(30 \mathrm{mcg})$, streptomycin (25mcg), and ciprofloxacin (5mcg). Reference strains of $S$. aureus (ATCC25923) and Escherichia coli (ATCC 25992) were used as control for the antibiogram tests (ANON, 2008).

The strains were classified as sensitive and resistant according to the standards defined by the CLSI (2013). Strains that had intermediate susceptibility were considered resistant in the statistical analysis. The Multiple Resistance Index (MAR) was calculated according to Krumperman (1983). All statistical analyses were descriptive. 


\section{Results and discussion}

The results showed a high prevalence of $S$. aureus (71.0\%) and $S$. agalactiae (68.0\%) pathogens in the farms. In the herds, $49.5 \%$ had both agents, $91.0 \%$ had one single agent and only $9.0 \%$ of the studied properties were negative for both pathogens (see Table 1).

Several studies have pointed to the high prevalence of $S$. aureus and S. agalactiae in Brazilian dairy herds. Brito et al. (1999) found a prevalence of $77.8 \%$ for $S$. aureus and $60 \%$ for $S$. agalactiae when they analyzed 6,315 milk samples from 48 dairy herds in the regions of Zona da Mata and Campo das Vertentes, both in the State of Minas Gerais, which is consistent with the results obtained in this study. Oliveira et al. (2013) studied approximately 6,000 lactating cows from 112 herds located in the States of Minas Gerais and Rio de Janeiro, and found a prevalence of $93.0 \%$ and $41.0 \%$ for $S$. aureus and $S$. agalactiae, respectively. Arcuri et al (2006) studied herds in the Southeast of Minas Gerais and North of Rio de Janeiro and found a prevalence of $91.66 \%$ and $50 \%$ for $S$. aureus and $S$. agalactiae, respectively, which points to a high prevalence of these pathogens in dairy herds in these states. In contrast, Zimmermann and Araújo (2017) studied the main causative agents of bovine mastitis in the city of Campo Mourão, State of Paraná, and found Staphylococcus spp. in 58.97\% of the properties and Streptococcus spp. isolates in $33.33 \%$ of the farms. Such finding shows that the prevalence of these pathogens can be variable among herds of different regions.

Table 1 - Prevalence of $S$. aureus and $S$. agalactiae in family-owned dairy herds in the Campo das Vertentes region, State of Minas Gerais.

\begin{tabular}{cccc}
\hline Pathogen & Presence or absence & Number of positive farms & $\%$ \\
\hline S. aureus & Present & 142 & 71.0 \\
& Absent & 58 & 29.0 \\
\hline S. agalactiae & Present & 136 & 68.0 \\
& Absent & 64 & 32.0 \\
\hline Both pathogens & Present & 99 & 49.5 \\
\hline Both pathogens & Absent & 18 & 9.0 \\
\hline
\end{tabular}


The high prevalence found in the present study for $S$. aureus and $S$. agalactiae (see Table 1) indicates that control measures for contagious mastitis have not been applied correctly. This points to a need for specific measures to control these contagious pathogens that impact the productivity of herds and the quality of milk, especially when it comes to the BMSCC (RODRIGUES et al., 2017).

The results of the antibiogram tests (see Table 2) indicate that the resistance rates ranged from $1.45 \%$ to $73.91 \%$ for $S$. aureus. The highest resistance indices were observed for polymyxin B (73.91\%), penicillin G (72.46\%), ampicillin (58.11\%), streptomycin (56.52\%), and tetracycline (46.38\%). The MARs for the isolates ranged from 0.00 to 0.76 , with a mean of 0.31 . Over $50 \%$ of the isolates showed multidrug resistance, with resistance to at least five different antibiotics (see Table 3). The most efficient antibiotics to combat $S$. aureus were sulfazotrim (with $98.55 \%$ of susceptible strains), florfenicol (95.65\%), chloramphenicol (92.75\%), nitrofurantoin (92.75\%), and ciprofloxacin (91.30\%). According to Santos, Leal and Rossi (2006), staphylococci are generally resistant to various antibiotics, including beta-lactams, aminoglycosides, chloramphenicol, quinolones, macrolides, and oxacillin.

Consistent with the present findings, Donatele, Motta, and Folly (2002) found high resistance rates for B-lactam antibiotics (82.9\%) and tetracyclines (24.4\%), and the highest sensitivity indices for sulfazotrim and gentamicin in 180 strains of $S$. aureus isolated from subclinical mastitis from herds in the State of Rio de Janeiro. Coelho et al. (2007) found high indices of resistance to penicillin (67.7\%) and ampicillin (64.4\%) in 29 clinical strains of $S$. aureus isolated from bovine mastitis.

Fontana et al (2010) studied the resistance of $S$. aureus strains isolated from 174 dairy cows from nine different properties in Jataí, State of Goiás. They found 100\% resistance to oxacillin, penicillin, and ampicillin. 
They claimed that indiscriminate use of antimicrobial drugs had contributed to the high rate of antibiotic resistance.

The present findings are consistent with the results of Costa et al. (2013). They evaluated the resistance of $352 S$. aureus isolates from 35 dairy herds in the South of Minas Gerais. They found high resistance for polymyxin B (82\%), followed by B-lactams: ampicillin (80.92) and penicillin (80.45\%). They also observed multi-resistance in the strains, with a MAR index ranging from 0.2 to 0.5 , unlike the present study that pointed to a MAR index ranging from 0.00 to 0.76 .

Also consistent with the present findings, Nunes, Cavaco, and Vilela (2007) evaluated the resistance of 234 mastitis pathogens isolates in dairy herds in Portugal and found high levels of resistance to penicillin (78.7\%) and ampicillin (65.6\%) in $S$. aureus isolates. Unlike the present findings, Freitas et al. (2005) found resistance rates higher than 50\% for gentamicin, lincomycin, tetracycline, and oxacillin in $S$. aureus isolates from dairy herds in the State of Pernambuco.

The antimicrobial susceptibility tests for $S$. agalactiae (Table 2) showed rates of resistance ranging from $19 \%$ to $90 \%$. The most resisted antibiotics were novobiocin (100\%), oxacillin (98.46\%), polymyxin B (96.92\%), streptomycin (96.92\%), and lincomycin (95.38\%). The most effective antibiotics were florfenicol (with 100\% of susceptible isolates), followed by sulfazotrim (84.62\%), nitrofurantoin (72.31\%), ciprofloxacin (69.23\%), and ampicillin (63.08\%). The MARs scores ranged from 0.19 to 0.90 , with an average of 0.62 . Besides, $98 \%$ of the strains showed multidrug resistance to the antibiotics (Table 3).

Silva et al. (2017) investigated the resistance to antibiotics used to control mastitis against strains of $S$. agalactiae isolates from dairy herds in different Brazilian regions. They found high rates of resistance to several antimicrobials, with $26.23 \%$ of resistance to erythromycin, $47.54 \%$ to tetracycline, $3.28 \%$ to gentamicin, $98.36 \%$ to sulfonamide, and $29.51 \%$ to 
clindamycin. All isolates were susceptible to penicillin, ceftiofur, and cephalothin. Such finding differs from those in the present study, especially regarding the resistance index for gentamicin, which reached $44.62 \%$ in this study. The high rate of resistance to $S$. aureus and $S$. agalactiae found in the present study might reflect the selective pressure of resistant strains due to misuse of antibiotics.

Table 2 - Results of antibiotic susceptibility tests in strains of Staphylococcus aureus and Streptococcus agalactiae isolates from bulk milk tanks from in family-owned dairy herds in Campo das Vertentes, State of Minas Gerais.

\begin{tabular}{|c|c|c|c|c|}
\hline \multirow[b]{2}{*}{ Antimicrobials } & \multicolumn{2}{|c|}{ Staphylococcus aureus } & \multicolumn{2}{|c|}{ Streptococcus agalactiae } \\
\hline & $\begin{array}{c}\text { Number of } \\
\text { resistant strains }\end{array}$ & $\begin{array}{c}\% \text { of resistant } \\
\text { strains }\end{array}$ & $\begin{array}{c}\text { Number of } \\
\text { resistant strains }\end{array}$ & $\begin{array}{c}\% \text { of resistant } \\
\text { strains }\end{array}$ \\
\hline Ampicillin & 43 & 58.11 & 24 & 36.92 \\
\hline Cephalotin & 20 & 28.99 & 42 & 64.62 \\
\hline Cefoperazone & 22 & 31.88 & 55 & 84.62 \\
\hline Cefotaxime & 25 & 36.23 & 58 & 89.23 \\
\hline Ceftiofur & 19 & 27.54 & 52 & 80.00 \\
\hline Ciprofloxacin & 6 & 8.70 & 20 & 30.77 \\
\hline Chloranphenicol & 5 & 7.25 & 29 & 44.62 \\
\hline Enrofloxacin & 14 & 20.29 & 33 & 50.77 \\
\hline Streptomycin & 39 & 56.52 & 63 & 96.92 \\
\hline Florfenicol & 3 & 4.35 & 0 & 0 \\
\hline Gentamicin & 14 & 20.29 & 29 & 44.62 \\
\hline Lincomycin & 24 & 34.78 & 62 & 95.38 \\
\hline Neomicin & 23 & 33.33 & 55 & 84.62 \\
\hline Nitrofurantoin & 5 & 7.25 & 18 & 27.69 \\
\hline Novobiocin & 32 & 46.38 & 65 & 100 \\
\hline Oxacillin & 28 & 40.58 & 64 & 98.46 \\
\hline Penicillin G & 50 & 72.46 & 58 & 89.23 \\
\hline Polymyxin B & 51 & 73.91 & 63 & 96.92 \\
\hline Sulfazotrim & 1 & 1.45 & 10 & 15.38 \\
\hline Tetracycline & 32 & 46.38 & 48 & 73.85 \\
\hline
\end{tabular}


Table 3 shows that $38(51.35 \%)$ in the $74 \mathrm{~S}$. aureus strains were resistant to more than five out of the 20 antibiotics tested in this study. The antibiotic susceptibility tests for $S$. agalactiae indicated that 64 stains (98.46\%) were resistant to more than five antibiotics. These results point to the high frequency of multi-resistance strains for both pathogens.

The present in-vitro results point to higher resistance rates for $S$. agalactiae as compared to $S$. aureus. Several studies have pointed to the greater difficulty in treating intramammary infections (IMI) caused by $S$. aureus as compared to IMI caused by $S$. agalactiae. This can be explained due to both increased antibiotic resistance rates and the mechanisms of escape to the immune system of the mammary glands, such as intracellular invasion, biofilm formation, leukotoxin production, IgA proteases, and other virulence factors in $S$. aureus strains adapted to bovine mammary glands (NOVICK; SCHLIEVERT; RUZIN, 2001; DELEO; CHAMBERS; CHAMBERS, 2009).

Variations in the antibiotic susceptibility found for the agents tested in the present study as compared to previous studies in the literature may be justified by spatial and temporal variations. They may also be due to the different methodologies employed in susceptibility testing (MIC or diffusion in discs), as to the origin of the isolates (clinical or subclinical mastitis, isolates of bulk milk tanks), and the selection pressure, due to the selective and indiscriminate use of antibiotics.

Table 3 - Multiple resistance in strains of Staphylococcus aureus and Streptococcus agalactiae isolates from bulk milk tanks in family-owned dairy herds in Campos das Vertentes, Minas Gerais.

\begin{tabular}{ccccccc}
\hline & \multicolumn{5}{c}{ Number of antimicrobials against which the strains were resistant } \\
\cline { 2 - 6 } Pathogens & 0 & 1 & 2 & 3 & 4 & $>5$ \\
\hline S. aureus & 4 & 6 & 8 & 6 & 12 & 38 \\
S. agalactiae & 0 & 0 & 0 & 0 & 1 & 64 \\
\hline
\end{tabular}


According to Myllys et al. (1994), antimicrobial resistance is an important factor in the establishment and spread of bacterial clones in a herd. It is associated with changes in management, such as the use of systematic antibiotic treatment, confinement and introduction of mechanical milking. These factors act as selective forces on mastitiscausing pathogens.

The present results point to high rates of resistance to the main antibiotics used in the treatment of mastitis in herds. This requires constant monitoring of susceptibility of the main pathogens causing mastitis, with a view to making a more careful choice of antibiotics in order to obtain higher cure rates and minimize drug resistance. Thus, permanent monitoring of pathogens and their antibiotic resistance indexes are indispensable to both animal health and human health.

\title{
Conclusions
}

The findings point to a high prevalence of $S$. aureus and $S$. agalactiae pathogens in family-owned dairy herds in Campo das Vertentes, State of Minas Gerais, Brazil. High levels of resistance and multidrug resistance of $S$. aureus and $S$. agalactiae were also found. Multi-resistance was found for both agents, with higher levels for $S$. agalactiae.

\section{Prevalence and antibiotic resistance of Staphylococcus aureus and Streptococcus agalactiae in family-owned dairy herds in the state of Minas Gerais, Brazil}

\begin{abstract}
Bovine mastitis is the most frequent disease in dairy herds worldwide, causing great economic losses to both producers and the industry. This disease has direct implications in public health due to the zoonotic potential of some agents involved in its etiology and the presence of antimicrobial residues in milk. Knowledge of the agents involved in its etiology and the susceptibility profiles to antimicrobials is of paramount
\end{abstract}


importance, give the multifactorial aspect of the disease and the importance of milk production in family farming. This study evaluated the prevalence of Staphylococcus aureus and Streptococcus agalactiae in family-owned herds in the Campo das Vertentes region, State of Minas Gerais, and the resistance of these pathogens to the most commonly used antibiotics in the treatment of mastitis in dairy herds. The study involved 200 properties, covering an area of approximately $12,564 \mathrm{~km}^{2}$. The prevalence of pathogens was carried out through microbiological analyses of milk samples from each farm's milk tank. Modified Baird-Parker Agar medium was used to detect $S$. aureus, and modified Edwards Agar medium, enriched with 5\% defibrinated sheep blood, was used to detect $S$. agalactiae. Disc diffusion method was used to evaluate resistance to antibiotics. The results showed high prevalence of $S$. aureus pathogens (71.0\%) and S. agalactiae (68.0\%) as well as high levels of multidrug resistance. The results show that the control of contagious mastitis in the herds is flawed, which indicates the need for more effective control of these pathogens and more judicious use of antibiotics to minimize resistance.

Keywords: Mastitis, Milk quality, Somatic cell count, BMSCC, Milk production.

\section{References}

ALENCAR, T. A.; MENDONÇA, E. da C.L.; MARQUES, V.F.; MELO, D.A.; ROJAS, A.C.M.; MOTTA, C.C.; SANTIAGO, G.S.; DUBENCZUK, F.C.; MEDEIROS, P.T. C.; COELHO, S. M.; SOUZA, M.M.S. Aspectos das condições higiênico-sanitárias em unidades leiteiras em municípios do estado do Rio de Janeiro, Brasil e análise dos agentes bacterianos envolvidos na etiologia das mastites. Revista Brasileira de Medicina Veterinária, v. 36, n. 4, p. 199-208. 2014.

ANON. Clinical Laboratory Standards Institute. Performance standards for antimicrobial disk and dilution susceptibility tests for bacteria isolated from animals, ed. Wayne: CLSI, 116p. 2008.

ARCURI, E. F.; BRITO, M. A.V. P.; BRITO, J. R. F.; PINTO, S. M.; ÂNGELO, F. F.; SOUZA, G. N. Qualidade microbiológica do leite refrigerado nas fazendas. Arquivo Brasileiro de Medicina Veterinária e Zootecnia, v. 58, n. 3, p. 440-46, 2006. https://doi.org/10.1590/S0102-09352006000300024 
BEZERRA, G. J.; SCHLINDWEIN, M. M. Agricultura familiar como geração de renda e desenvolvimento local: uma análise para Dourados, MS, Brasil. Interações (Campo Grande), vol.18, n.1, p .3-15, 2017. https://doi.org/10.20435/1984-042X2016-v.18-n.1(01)

BRITO, M. A. V. P.; BRITO, J. R. F. Qualidade do leite. In: MADALENA, F.H.; MATOS, L.L. de; HOLANDA JR, E.V. Produção de leite e a sociedade. FEPMVZ, Belo Horizonte, p. 61-74, 2001.

BRITO, M. A. V.; BRITO. J. R.; RIBEIRO, M. T.; VEIGA, V. M. O. Padrão de infecção intramamária em rebanhos leiteiros: exame de todos os quartos mamários das vacas em lactação. Arquivo Brasileiro de Medicina Veterinária e Zootecnia, v. 51, n. 2, p. 129-35, 1999. https://doi.org/10.1590/S0102-09351999000200001

CLINICAL AND LABORATORY STANDARDS INSTITUTE - CLSI. Performance Standards for Antimicrobial Disk and Dilution Susceptibility Tests for Bacteria Isolated From Animals. 3. Ed. Pennsylvania, USA, 2013.

COELHO, S.M.O.; MENEZES, R.A; SOARES L.C.; PEREIRA, I.A.; GOMES, L.P.; SOUZA, M.M.S. Mapeamento do perfil de resistência e detecção do gene mecA em Staphylococcus aureus e Staphylococcus intermedius oxacilina-resistentes isolados de espécies humanas e animais. Ciência Rural. v. 37, n. 1, p. 195-200, 2007. https://doi.org/10.1590/S0103-84782007000100031

COSTA, G. M.; BARros, R. A.; CUSTÓDIO, D. A. C.; PEREIRA, U. P.; FIGUEIREDO, D. J.; SILVA N. Resistência a antibióticos em staphylococcus aureus isolados de mastite em bovinos leiteiros de Minas Gerais, Brasil. Arquivos do Instituto Biológico. v. 80, n. 3, p. 297-302. 2013.

https://doi.org/10.1590/S1808-16572013000300006

CUNHA, A. F.; BRAGANÇA, L. J.; QUINTÃO, L. C.; SILVA, S. Q.; SOUZA, F. N. de; CERQUEIRA, M. M. O. P. Prevalência, etiologia e fatores de risco de mastite 
subclínica em rebanhos leiteiros de Viçosa-MG. Acta Veterinária Brasílica, v.9, n.2, p.160-166, 2015.

DELEO, F. R.; CHAMBERS, H. F.; CHAMBERS, H. F. Reemergence of antibioticresistant. Journal of Clinical Investigation, v. 119, n. 9, p. 2464-2474, 2009. https:// doi.org/10.1172/JCI38226

DONATELE, D. M.; MOTTA O. V.; FOLLY, M. M. Perfil antimicrobiano de linhagens de Staphylococcus spp. coagulase positiva na mastite subclínica de vacas leiteiras nas regiões norte e noroeste do estado do Rio de Janeiro. Revista Napgama, v. 5, n. 2, p. 3-6, 2002.

ELIAS, A. O.; CORTEZ, A.; BRANDÃO, P. E. ; SILVA, R. C.; LANGONI, H.. Molecular detection of Streptococcus agalactiae in bovine raw milk samples obtained directly from bulk tanks. Research in Veterinary Science, v. 93, $\mathrm{n}^{0} 1, \mathrm{p}$. 34-38, 2012. https://doi.org/10.1016/j.rvsc.2011.07.016

ERSKINE, R., CULLOR,J., SCHAELliBAUM, M., YANCEY, B.; ZECCONI, A. Bovine mastitis pathogens \& trends in resistance to antibacterial drugs. IN: 58th Annual Meeting National Mastitis Council. 2004. Annual Meeting Proceedings, p. 1-15. 2004.

FREITAS, M.F.L.; PINHEIRO, JÚNIOR J.W.; STAMFORD, T.L.M.; RABELO, S.S.A.; SILVA, D.R.; SILVEIRA FILHO, V.M.; SANTOS, F.G.B.; SENA M.J.; MOTA, R.A. Perfil de sensibilidade antimicrobiana in vitro de Staphylococcus coagulase positivos isolados de leite de vacas com mastite no agreste do Estado de Pernambuco. Arquivos Instituto Biológico, v. 72, n. 2, p. 171-177, 2005.

FONTANA, V. L. D. S.; ALMEIDA, M. J. S. M. G.; LEITE, C. Q. F.; MIRTA, E. T.; FUSCO, A. M.; FONTANA, S. C. A. P.; SOUZA, C. M. DE; EURIDES, A. Etiologia da mastite bovina subclínica, sensibilidade dos agentes às drogas antimicrobianas e detecção do gene da B- lactamase em Staphylococcus aureus agentes à estas drogas. Veterinária e Zootecnia, v. 17, n. 4, p. 568-76, 2010. 
GUANZIROLI, C. E.; CARDIM, S. E. C. S. Novo retrato da agricultura familiar: o Brasil redescoberto. Brasília: 2000. Projeto de cooperação técnica INCRA/FAO. Disponível em: <http://www.incra.gov.br/sade/doc/AgriFam.htm>. Acessado em: 18 março de 2018.

INSTITUTO BRASILEIRO DE GEOGRAFIA E ESTATÍSTICA - IBGE. Estatística da Produção Pecuária 2017, v. 1, nº 1, p. 1-78, mar. 2017. Disponível em: $<$ http://www.ibge.gov.br/home/estatistica/indicadores/agropecuaria/ producaoagropecuaria > Acessado em 2 de outubro de 2017.

INSTITUTO BRASILEIRO DE GEOGRAFIA E ESTATÍSTICA - IBGE. Censo Agropecuário 2006. Brasília. Disponível em $<$ https://ww2.ibge.gov.br/home/estatistica/economia/agropecuaria/censoagro/ 2006 segunda apuracao/default.shtm> Acessado em 28 de novembro 2018.

KEEFE, G. Update on control of Staphylococcus aureus and Streptococcus agalactiae for management of mastitis. The Veterinary Clinics of North America. v. 28, n. 2, p. 203-216, jul. 2012. https://doi.org/10.1016/j.cvfa.2012.03.010

KRUMPERMAN, P. H. Multiple antibiotic resistance indexing of Escherichia coli to identify high-risk sources of fecal contamination of foods. Multiple antibiotic resistance indexing of Escherichia coli to identify high-risk sources of fecal contamination of foods. Applied \& Environmental Microbiology. v.46, n. 1, p. 16570, 1983.

LANGONI, H.; PENACHIOI, D. S.; CITADELLAI, J. C.C.; LAURINOI, F.; FACCIOLI-MARTINSI, P. Y.; LUCHEIS, S. B.; MENOZZ, B. D.; SILVA, A. V. DA. Aspectos microbiológicos e de qualidade do leite bovino. Pesquisa Veterinária Brasileira. v. 31, n. 12, p. 1059-1065, 2011. https://doi.org/10.1590/S0100736X2011001200004 
LOPES, M. A.; DEMEU, F.A.; ROCHA, C.M.B.M. DA; COSTA, G.M.; NETO, A. F.; SANTOS, G. DOS. Avaliação do Impacto Econômico da Mastite. Arquivos do Instituto Biológico, v. 79, p. 477-483, 2012. https://doi.org/10.1590/S1808$\underline{16572012000400003}$

MYLLYS, V.; HONKANEN-BUZALSKI, T.; HUOVINEN, P.; SANDHOLM, M.; NURMI E. Association af changes in the bacterial ecology of bovine mastitis with changes in the use of milking machines \& antibacterial drugs. ActaVeterinaria Scainavica, v. 35, n. 4, p. 363-69, 1994.

MINISTÉRIO DA AGRICULTURA, PECUÁRIA E ABASTECIMENTO - MAPA. 2017. Conheça o Plano Safra da Agricultura Familiar 2017/2020. ANO DE PUBLICAÇÃO. Disponível em <http://www.mda.gov.br/sitemda/plano-safra-daagricultura-familiar-20172020> Acesso em: 29 de novembro de 2018.

MINISTÉRIO DA AGRICULTURA, PECUÁRIA E ABASTECIMENTO - MAPA. 2018. Agricultura familiar do Brasil é $8^{a}$ maior produtora de alimentos do mundo. Disponível em <http://www.mda.gov.br/sitemda/noticias/agricultura-familiar-dobrasil-\%C3\%A9-8\%C2\%AA-maior-produtora-de-alimentos-do-mundo $>$ Acesso em: 29 de agosto de 2019.

NATIONAL MASTITIS COUNCIL RESEARCH COMMITTEE - NMC. Microbiological procedures for the diagnosis of bovine udder infection and determination of milk quality. 4 ed. Wisconsis, USA, 2004. 47 p.

NOVICK, R. P.; SCHLIEVERT, P.; RUZIN A. Pathogenicity and resistance Islands of Staphylococci. Microbes \& Infection, v. 3, n. 7, p. 585-94, 2001. https://doi.org/10.1016/S1286-4579(01)01414-9

NUNES, S. F.; CAVACO, L. M.; VILELA C. L. Antimicrobial Susceptibility Traits of Subclinical Bovine Mastitis Pathogens in Portugal. Revista Portuguesa de CienciasVeterinarias, v. 102, p. 275-80, 2007. 
OLIVEIRA, E. F. DE; BRITO, M. A. V.; LANGE, C. C.; MENDONÇA, L. C.; MEURER I. R. Prevalência de patógenos contagiosos em rebanhos da associação dos criadores de gado holandês do estado de Minas Gerais, 2011-2012. Veterinária e Zootecnia, v. 20, n 1, p. 265-68. 2013.

OLIVER, S.P.; GONZÁLEZ, R.N.; HOGAN, J.S.; JAYARAO, B.M.; OWENS, W.E. Microbiological procedures for the diagnosis of bovine udder infection and determination of milk quality. 4th National Mastitis Council, Verona, WI. 46p. 2004.

OLIVEIRA, U.V.; GALVÃO G. S.; RIBEIRO A.R. P.; ANDREOLI J.L.; MUNHOZ A.D. Eficácia in vitro da gentamicina sobre bactérias isoladas de vacas com mastite subclínica na microrregião Ilhéus-Itabuna, Bahia. Revista Brasileira de Medicina Veterinária, v. 34, n. 3, p. 213-218, 2012.

OLIVEIRA, A. A.; MELO C. B. DE; AZEVEDO H. C. Diagnóstico e determinação microbiológica da mastite em rebanhos bovinos leiteiros nos tabuleiros costeiros de Sergipe. Ciência Animal Brasileira, v. 10, n. 1, p. 226-230, 2009.

OIE. Risk Assessment for antimicrobial resistance arising from the use of antimicrobials in animals. In: Terrestrial Animal Health Code.World Organization for Animal Health, Annual Meeting Proceedings. p. 1-6. Paris, 2010.

OVIEDO-BOYSO, J.; VALDEZ-ALARCÓN, J. J.; CAJERO-JUÁREZ, M; OCHOAZARZOSA A,; LÓPEZ-MEZA, J. E.; BRAVO-PATIÑO, A.; BAIZABAL-AGUIRRE, V. M. Innate immune response of bovine mammary gland to pathogenic bacteria responsible for mastitis. The Journal of infection, v. 54, n. 4, p. 399-409, abr. 2007. https://doi.org/10.1016/j.jinf.2006.06.010

PETER, C. M.; PICOLI, T.; PONZILACQUA, B.; LATOSINSKI, G.; ZANI, J. L.; FISCHER, G. Contagem de staphylococcus aureus e staphylococcus spp. e sua relação com a contagem bacteriana total em unidades de produção leiteiras de 
municípios da região Sul do Rio Grande do Sul. Veterinária e Zootecnia, v. 20, p. 330-331, 2013.

RAJALA-SCHULTZ, P. J.; TORRES, A. H.; DEGRAVES, F. J.; GEBREYES, W. A.; PATCHANEE P. Antimicrobial resistance and genotypic characterization of coagulase-negative staphylococci over the dry period. Veterinary Microbiology, v.134, n. 1, p. 55-64. 2009. https://doi.org/10.1016/j.vetmic.2008.09.008

REYHER, K. K.; HAINE, D,; DOHOO, I. R.; REVIE, C. W.. Examining the effect of intramammary infections with minor mastitis pathogens on the acquisition of new intramammary infections with major mastitis pathogens-A systematic review and meta-analysis. Journal of Dairy Science, v. 95, n. 11, p. 6483-6502, nov. 2012. https://doi.org/10.3168/jds.2012-5594

RODRIGUES, L. G.; AQUINO, M. H. C.; SILVA, M. R.; MENDONÇA, L. C.; MENDONÇA, J. F. M.; SOUZA, G. N.; RODRIGUES L. G. A time series analysis of bulk tank somatic cell counts of dairy herds located in Brazil and the United States. Ciência Rural. v. 47, nº. 4, p. 1-6. 2017. https://doi.org/10.1590/0103$\underline{8478 \mathrm{cr} 20160618}$

SAAB, A. B.; ZAMPROGNA, T. O.; LUCAS, T. M.; MARTINI, K. C.; MELLO, P. L. Prevalência e etiologia da mastite bovina na região de Nova Tebas, Paraná. Semina, v. $35, \quad$ n. $2, \quad$ p. 835-843, 2014. https://doi.org/10.5433/1679$\underline{0359.2014 \mathrm{v} 35 \mathrm{n} 2 \mathrm{p} 835}$

SANTOS, C. D. M.; LEAL, G. A.; ROSSI, D. A. Frequência e suscetibilidade a antibióticos de Staphylococcus spp. isolados de leite de vacas com mastites recorrentes de rebanhos da região de Uberlândia - MG. Veterinária Notícias, v.12, n. 2, p. 83-88, 2006.

SAWANT, A.A.; PILLAI, S.R.; JAYARAO, B. M. Evaluation of five selective media for isolation of catalase negative gram-positive cocci from raw milk. Journal of 
Dairy Science. v. 85, p. 1127-1132, 2002. https://doi.org/10.3168/jds.S0022$\underline{0302(02) 74174-X}$

SCHOELLERS, N.P.; .INGHAM, C. Comparison of the Baird-Parker agar and 3MTMPetrifilmTMrapid S. aureus count plate methods for detection and enumeration of Staphylococcus aureus. Food Microbiology, v. 18, n. 6, p. 581-587, 2001. https://doi.org/10.1006/fmic.2001.0432

SILVA, J. R. Avaliação da virulência e susceptibilidade a antibióticos em Streptococcus agalactiae isolados de mastite bovina de rebanhos brasileiros. Dissertação (Mestrado em Medicina Veterinária) - Universidade Federal de Lavras, Lavras, 2015.

SOLA, M. C.; FEISTEL, J. C.; OLIVEIRA, A. P.; REZENDE, C. S. M. Manutenção de microrganismos: conservação e viabilidade. Enciclopédia Biosfera, v. 8, n. 14, p. 1398-1418, jun. 2012.

UNITED STATES DEPARTMENT OF AGRICULTURE - USDA. Produção de leite USA. 2012 Disponível em: <http://www.ers.usda.gov/datafiles/Agricultural BaselineProjection Files/Dairy1-3.xls > . Acesso em: 20 de novembro de 2017.

ZIMERMANN, K. F.; ARAÚJO M. E. M. Mastite bovina: agentes etiológicos e susceptibilidade a antimicrobianos. Revista Ciências Exatas e da Terra e Ciências Agrárias, v. 12, n. 1, p.1-7, jan./jul, 2017.

ZOCCAL, R.; SOUZA, A. D. DE.; GOMES, A. T. Produção de leite na agricultura familiar. In: MARTINS, C. E.; CÓSER, A. C.; SOUZA, A. D.; FRANCO, P. R. V.; MAGAlHÃES, F. A. R.; LEMOS, A. M.; BERNARDO, W. F. Tecnologias alternativas para a produção de leite e derivados em bases sustentáveis. Juiz de Fora -MG, 2004. p. 19-34. 